\title{
Seasonal and developmental variation in the lipids of Acanthostepheia malmgreni (Amphipoda) from the hyperbenthos of a cold-ocean environment (Conception Bay, Newfoundland)
}

\author{
Nicole B. Richoux*, Raymond J. Thompson, Don Deibel and Christopher C. Parrish \\ Ocean Sciences Centre, Memorial University, St John's, Newfoundland and Labrador, AlC 5S7, Canada. \\ *Corresponding author, e-mail:nrichoux@mun.ca
}

\begin{abstract}
Total lipid (TL) and lipid-class composition in Acanthostepheia malmgreni (Crustacea: Amphipoda) from $240 \mathrm{~m}$ depth in Conception Bay were determined from samples collected monthly throughout 1999 and 2000. Variation in lipids among life history stages was studied in relation to the reproductive cycle of $A$. malmgreni and the timing of the major annual sinking event following the spring phytoplankton bloom in April. Total lipid remained relatively constant in first year juveniles [mean 4.4\% dry mass (DM)], after which it gradually increased with the first signs of development of sexual characteristics and the sedimentation of spring bloom material in May. Triacylglycerol (TAG) was the dominant neutral lipid in all stages, with phospholipid (PL) the dominant polar lipid. Highest net accumulation of TL and TAG occurred in a group of large age 2+ individuals from October 1998 to May 1999, and in age 1+ immature males and

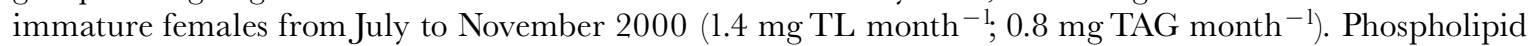
quantities within the population were relatively constant at $\sim 2 \%$ DM. Maximum TL in the population $(13 \% \mathrm{DM})$ was observed in large adults and some large immature individuals, and significant decreases in both TL and PL were recorded in mature females during the brooding period. This study reveals a dependence of A. malmgreni on seasonal lipid accumulation for reproduction, and a clear trophic link between the amphipod population and the pelagic production cycle.
\end{abstract}

\section{INTRODUCTION}

The hyperbenthos is a poorly understood but highly productive oceanic realm that is difficult to sample, resulting in relatively few studies on hyperbenthic ecology. However, the information available suggests that hyperbenthic zooplankton successfully exploit a variety of energy sources and are important intermediate trophic links between small (bacteria, phytoplankton, detritus and meiofauna) and large (fish and predatory invertebrates) size-fractions in the marine food web (Mees \& Jones, 1997). Zooplankton commonly rely on stored lipids to reproduce or to survive through periods of low food availability, and determination of seasonal lipid content with respect to life cycle can be critical for an understanding of the energetic role of a species within a food web. Seasonal lipid patterns in keystone species, particularly in the energy storage lipid classes, can be used to deduce the critical periods of energy transfer from one trophic level to another (Arts et al., 1992). Sympatric species with dissimilar life styles and nutritional requirements may have different critical periods of energy accumulation and utilization.

Acanthostepheia malmgreni Goës, a semelparous breeder with a 2.5-y life span (Richoux et al., 2004b), was the most common and abundant amphipod in the hyperbenthos of the depositional zone in Conception Bay, Newfoundland, from April 1997 to June 1998 (Deibel et al., unpublished data). Brooding requires a five-month period, and juveniles are released into the hyperbenthos during April and May (Richoux et al., 2004b). Juveniles feed on small particles, including phytoplankton and detritus (N.B.R., unpublished data), whereas older stages prey on copepods and other small invertebrates (SainteMarie \& Brunel, 1985). Acanthostepheia malmgreni is capable of rapid bursts of swimming (Sainte-Marie \& Brunel, 1985), although in the laboratory individuals often remain partially buried in the sediment (N.B.R., unpublished data). There have been no investigations to determine whether the population migrates vertically within Conception Bay.

The aim of the present study was to examine the seasonal energy storage in Acanthostepheia malmgreni, with particular emphasis on the relationships among lipid content and composition, the reproductive cycle and the timing of spring bloom sedimentation. If the population depends on the annual spring bloom to provide sufficient energy for reproduction and survival, lipid levels should rise shortly after the fallout of the bloom. The following questions were addressed: (1) does lipid storage vary according to the reproductive cycle, seasonal food availability, or both? (2) If lipids are stored seasonally, in what form are they stored? (3) When are the lipid maxima and minima and what is their nature? (4) How do areal lipid concentrations in the population change over a two-year period? (5) How is lipid content affected during periods 
of starvation? This paper is one of a series focusing on the population and lipid dynamics of two hyperbenthic zooplankton species in a cold-ocean ecosystem (Richoux et al., 2004a,b, in press).

\section{MATERIALS AND METHODS}

\section{Study site and sample collection}

Samples of Acanthostepheia malmgreni were collected approximately monthly from October 1998 to November 2000 from $240 \mathrm{~m}$ depth in the hyperbenthos of Conception Bay, a fjord-like bay on the east coast of Newfoundland $(100 \mathrm{~km}$ length $\times 30 \mathrm{~km}$ width) with a $150 \mathrm{~m}$ deep sill at the mouth and steep slopes near the shores (deYoung et al., 1993). An inshore branch of the Labrador Current supplies cold water $\left(<0^{\circ} \mathrm{C}\right)$ to deep regions of the bay year-round. Detailed sampling methods for both the hyperbenthos and the water column (physical data) are described by Richoux et al. (2004a). Sampling was done from a $13-\mathrm{m}$ boat using an epibenthic sled equipped with a $500-\mu \mathrm{m}$ mesh net tapered to a closed cod end. The mouth area of the sled $\left(0.3 \mathrm{~m}^{2}\right)$ permitted sampling of organisms from the sediment surface to $60 \mathrm{~cm}$ above the bottom. Tows lasted 20 to $30 \mathrm{~min}$, starting at coordinates $47^{\circ} 30.5^{\prime} \mathrm{N} 53^{\circ} 07.5^{\prime} \mathrm{W}$ and ending near $47^{\circ} 32.5^{\prime} \mathrm{N} 53^{\circ} 07.0^{\prime} \mathrm{W}$.

\section{Specimens}

Live, depurated amphipods (Acanthostepheia malmgreni) were sorted into life history stages (Table 1). The body lengths of one to five straightened individuals from each free-living stage (sample size dependent on availability) were measured to the nearest $0.5 \mathrm{~mm}$ (frontal edge of the eyes to the telson tip). Embryos were removed from brood sacs for counting, although each brood was maintained as a unit for lipid analysis. Each sample was rinsed with $1-\mu \mathrm{m}$ filtered seawater and stored in chloroform under nitrogen at $-20^{\circ}$ C. Dry mass (DM) of each amphipod was calculated from body length using an equation derived for the appropriate life history stage (four equations in all), and
DM of each brood was calculated from brood size (Table 1; Richoux et al., 2004b). Approximately 200 live amphipods collected on 14 August 2000 were placed in several 18-1 containers of $1-\mu \mathrm{m}$ filtered, aerated seawater at $\sim 2^{\circ} \mathrm{C}(\sim 30$ individuals in each container). The amphipods were maintained without food, light or sediment for 2.5 months to examine the changes in lipids in response to starvation. Exuviae and dead amphipods were removed daily, and the filtered seawater replaced every few days. Triplicate samples (sexes not separated) for lipid or DM analyses were collected every 3 to 14 days until 1 November 2000, when daily mortality was $\sim 50 \%$.

\section{Lipid analyses}

Lipids were extracted from amphipods and broods using a modified Folch procedure (Parrish, 1999). Freeliving stages were pooled on a few occasions when juveniles were very small. Each sample was homogenized with a metal rod in chloroform:methanol (2:1, v:v), and the bottom lipid layer removed and combined with repeated chloroform washes. Concentrated lipid extracts were spotted on silica gel-coated rods (Chromarods-SIII) and lipid classes separated by thin-layer chromatography (TLC) and quantified by flame ionization detection (FID) with an Iatroscan MK V (Parrish, 1999). Nine standards (Sigma-Aldrich Canada Ltd) were used to identify and quantify lipid classes in the extracts: n-nonadecane [hydrocarbon $(\mathrm{HC})$ ], cholesteryl palmitate [steryl ester (SE)], 3-hexdecanone [ketone (KET)], tripalmitin [triacylglycerol (TAG)], palmitic acid [free fatty acid (FFA)], 1-hexadecanol [alcohol (ALC)], cholesterol [sterol (ST)], 1-monopalmitoyl-rac-glycerol [acetone-mobile polar lipid (AMPL)], and dipalmitoyl DL- $\alpha$-phosphatidylcholine [phospholipid (PL)]. Steryl esters were not discernible from wax esters (WE) and were treated as one class (SE/ $\mathrm{WE})$. Methyl esters (ME), identified by their position between SE/WE and KET, were quantified using the calibration equation for KET. Diacylglycerols (DG) followed the ST peak and were quantified using the AMPL calibration. When peak splitting was observed in the TAG and FFA regions, additional developments using alternative

Table 1. Acanthostepheia malmgreni. Life history stages, approximate size ranges of individual amphipods and entire broods, and equations used to calculate amphipod dry mass ( $D M, \mathrm{mg}$ ) from body length ( $L, \mathrm{~mm}$ ) and brood $D M(\mathrm{mg})$ from brood size ( $F c$, embryos brood ${ }^{-1}$ ) (Richoux et al., 2004b). Free-living juveniles $<7 \mathrm{~mm}$ were not sampled because they probably occurred at a different depth.

\begin{tabular}{|c|c|c|c|c|}
\hline $\begin{array}{l}\text { Life history } \\
\text { stage }\end{array}$ & $\begin{array}{l}\text { Body length } \\
\text { (mm) or brood } \\
\text { size }(\mathrm{embryos} \\
\left.\text { brood }^{-1}\right)\end{array}$ & $\begin{array}{l}\text { Dry mass } \\
\quad(\mathrm{mg})\end{array}$ & Equation & Characteristics \\
\hline $\begin{array}{l}\text { Embryos } \\
\quad \text { (whole broods) }\end{array}$ & $142-339$ & $21-61$ & $\mathrm{DM}=0.181 \times \mathrm{Fc}-0.340$ & Embryos are within a brood sac \\
\hline Juveniles & $7.0-23$ & $1.7-42$ & $\mathrm{DM}=0.00673 \times 1^{2.87}$ & No visible secondary sexual characteristics \\
\hline \multirow[t]{2}{*}{ Immatures } & $14-35$ & $29-164$ & $\mathrm{DM}=0.00480 \times 1^{3.01}$ & Female: has developing oostegites \\
\hline & $17-24$ & $23-62$ & $\mathrm{DM}=0.00710 \times 1^{2.85}$ & Male: has developing penes \\
\hline Mature females & $24-32$ & $92-149$ & $\mathrm{DM}=0.00480 \times 1^{3.01}$ & Fully developed brood sac with embryos \\
\hline Spent females & $28-32$ & $74-123$ & $\mathrm{DM}=0.00955 \times \mathrm{l}^{2.73}$ & Fully developed empty brood sac \\
\hline Mature males & $20-33$ & $37-162$ & $\mathrm{DM}=0.00710 \times 1^{2.85}$ & Well developed penes \\
\hline Non-sexed individuals & $23-34$ & $52-168$ & $\mathrm{DM}=0.00673 \times \mathrm{l}^{2.87}$ & $\begin{array}{l}\text { May include immature males, immature } \\
\text { females, and/or mature males }\end{array}$ \\
\hline
\end{tabular}


solvent systems adequately separated the peaks (Parrish, 1999). The separated lipid molecular species (polyunsaturated and saturated FFA and TAG) were identified using the standards palmitic acid (C16:0), docosahexaenoic acid (C22:6), tripalmitin $(3 \times \mathrm{Cl} 16: 0)$, and triarachidonin $(3 \times \mathrm{C} 20: 4)$. For those samples exhibiting peak-splitting, a TAG:FFA ratio was determined from the additional developments and applied to the sum of TAG and FFA, previously quantified by the standard TLC-FID procedure. Total lipid (TL) concentration in each extract was calculated by summing the lipid classes.

\section{Areal concentrations of lipids}

Areal concentrations of TL and TAG $\left(\mathrm{mg} \mathrm{m}^{-2}\right)$ in Acanthostepheia malmgreni in the hyperbenthos were calculated following Arts et al. (1992). Briefly, adjusted amphipod density values derived by Richoux et al. (2004b) were multiplied by mean TL and TAG ind ${ }^{-1}$ for each life history stage within a cohort. Adjusted, or back-

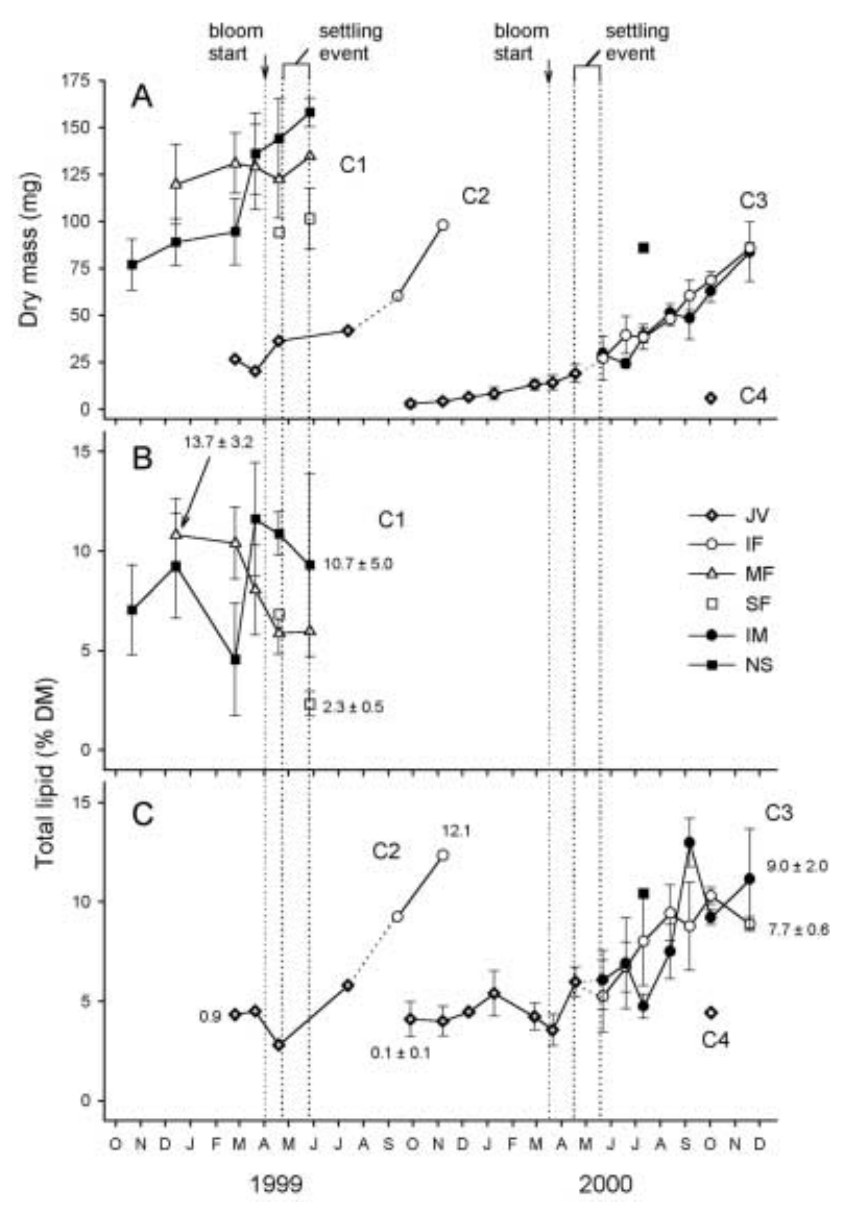

Figure 1. Acanthostepheia malmgreni. (A) Changes in dry mass $(\mathrm{mg})$ in lipid samples; (B) changes in total lipid (\% DM) in cohort $1(\mathrm{C} 1)$; and $(\mathrm{C})$ changes in total lipid ( $\% \mathrm{DM})$ in cohorts 2 and 3 (C2, C3) [only one C4 sample was available for lipid analysis; JV, juveniles; IF, immature females; MF, mature females (includes brooded embryos); SF, spent females; IM, immature males; NS, non-sexed]. Superimposed values represent total lipid content $\left(\mathrm{mg}\right.$ ind $\left.{ }^{-1}\right)$; dotted lines within a cohort represent transition periods between stages; vertical dotted lines represent bloom start and settling times. Values are means $\pm \mathrm{SD}$. calculated, data were required because amphipod density in later samples was often greater than that in earlier samples within a single cohort. Areal lipid concentrations for each sample date were determined by summing the areal values for each stage and cohort. Since free-living juveniles ( $4 \mathrm{~mm}$ at release) were not collected before they reached $7 \mathrm{~mm}$ length (Richoux et al., 2004b), areal calculations are considered to be underestimates.

\section{Statistical analyses}

Rates of lipid accumulation and utilization were determined from slopes of linear sections of least squares

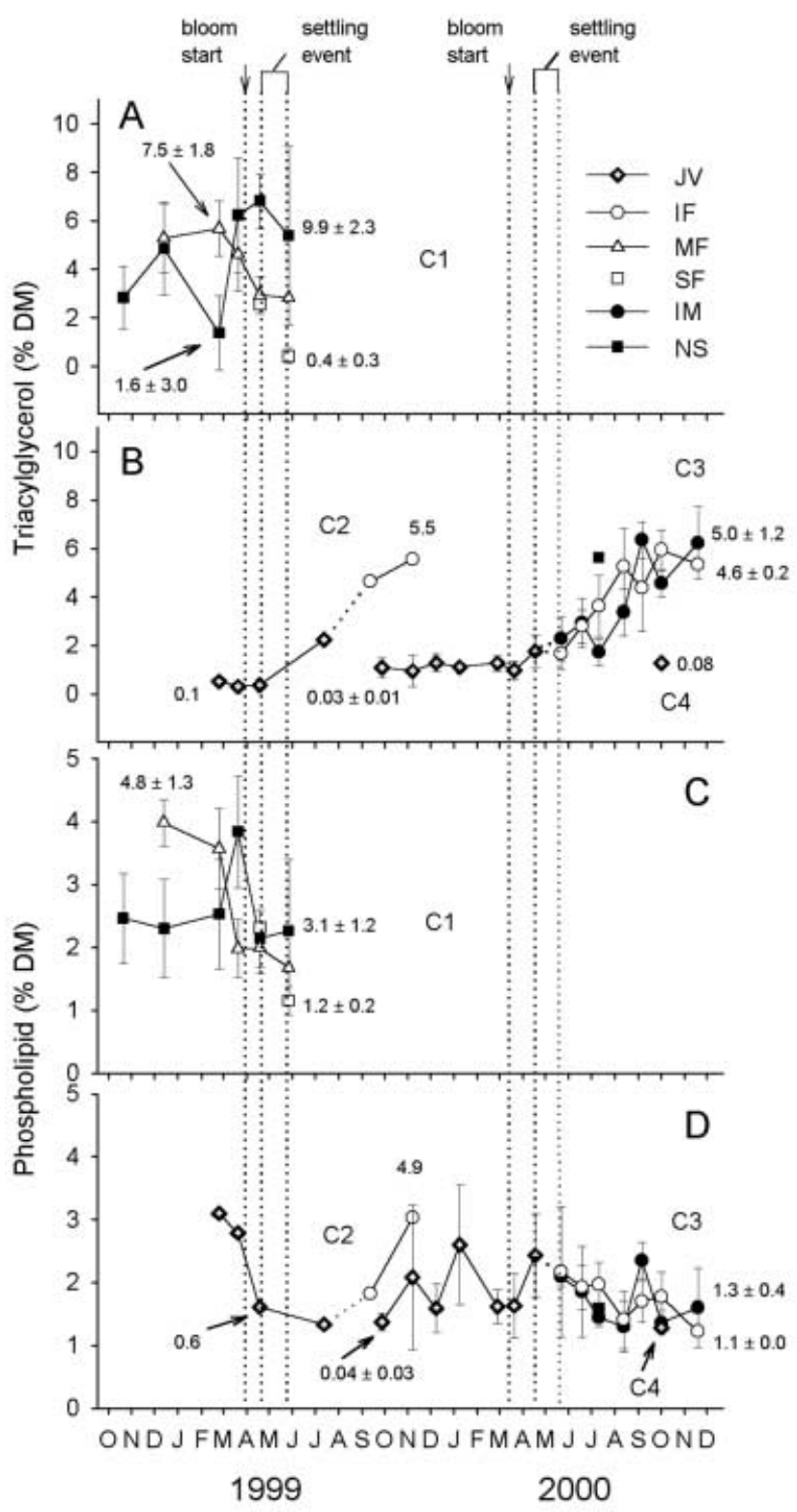

Figure 2. Acanthostepheia malmgreni. Changes in triacylglycerol $(\% \mathrm{DM})$ in $(\mathrm{A})$ cohort $1(\mathrm{Cl})$ and $(\mathrm{B})$ cohorts 2 and $3(\mathrm{C} 2, \mathrm{C} 3)$ and in phospholipid in $(\mathrm{C}) \mathrm{C} 1$ and $(\mathrm{D}) \mathrm{C} 2$ and C3. Superimposed values represent lipid class content $\left(\mathrm{mg}_{\text {ind }}{ }^{-1}\right)$; dotted lines within a cohort represent transition periods between stages; vertical dotted lines represent bloom start and settling times. Values are means \pm SD. Abbreviations as per Figure 1. 
Table 2. Acanthostepheia malmgreni. Lipid class composition of cohort 1. Data are grand means $\pm S D$ calculated for stages collected on more than one sampling date.

\begin{tabular}{|c|c|c|c|c|c|c|}
\hline \multirow[b]{2}{*}{ Class } & \multicolumn{2}{|c|}{$\begin{array}{c}\text { Mature females } \\
\text { December 1998-May } 1999\end{array}$} & \multicolumn{2}{|c|}{$\begin{array}{c}\text { Spent females } \\
\text { April 1999-May } 1999\end{array}$} & \multicolumn{2}{|c|}{$\begin{array}{c}\text { Non-sexed adults } \\
\text { October 1998-May } 1999\end{array}$} \\
\hline & $\% \mathrm{DM}$ & $\% \mathrm{TL}$ & $\% \mathrm{DM}$ & $\% \mathrm{TL}$ & $\% \mathrm{DM}$ & $\% \mathrm{TL}$ \\
\hline $\mathrm{HC}$ & $0.06 \pm 0.03$ & $0.64 \pm 0.27$ & 0.00 & $0.14 \pm 0.20$ & $0.04 \pm 0.02$ & $0.41 \pm 0.16$ \\
\hline $\mathrm{SE} / \mathrm{WE}$ & $0.02 \pm 0.01$ & $0.17 \pm 0.17$ & $0.01 \pm 0.01$ & $0.29 \pm 0.41$ & $0.11 \pm 0.12$ & $1.12 \pm 1.39$ \\
\hline $\mathrm{ME}$ & 0.00 & $0.02 \pm 0.04$ & $0.01 \pm 0.01$ & $0.21 \pm 0.30$ & $0.01 \pm 0.02$ & $0.07 \pm 0.16$ \\
\hline KET & $0.02 \pm 0.02$ & $0.31 \pm 0.20$ & 0.00 & 0.00 & $0.02 \pm 0.01$ & $0.31 \pm 0.22$ \\
\hline TAG & $4.27 \pm 1.32$ & $51.44 \pm 4.15$ & $1.50 \pm 1.51$ & $27.11 \pm 14.68$ & $4.59 \pm 2.08$ & $45.80 \pm 16.80$ \\
\hline FFA & $0.32 \pm 0.21$ & $4.47 \pm 3.47$ & $0.68 \pm 0.56$ & $13.97 \pm 2.49$ & $0.46 \pm 0.30$ & $5.58 \pm 2.71$ \\
\hline ALC & 0.00 & 0.00 & 0.00 & $0.12 \pm 0.17$ & $0.02 \pm 0.03$ & $0.24 \pm 0.40$ \\
\hline $\mathrm{ST}$ & $0.55 \pm 0.11$ & $6.79 \pm 1.16$ & $0.44 \pm 0.14$ & $11.55 \pm 5.28$ & $0.50 \pm 0.09$ & $6.57 \pm 2.36$ \\
\hline $\mathrm{DG}$ & $0.03 \pm 0.02$ & $0.43 \pm 0.30$ & $0.04 \pm 0.04$ & $0.66 \pm 0.40$ & $0.08 \pm 0.06$ & $0.94 \pm 0.34$ \\
\hline Neutral & $5.26 \pm 1.33$ & $64.18 \pm 5.15$ & $2.67 \pm 2.22$ & $54.06 \pm 11.22$ & $5.81 \pm 2.40$ & $61.06 \pm 16.25$ \\
\hline AMPL & $0.33 \pm 0.15$ & $3.97 \pm 1.28$ & $0.18 \pm 0.16$ & $3.62 \pm 0.86$ & $0.38 \pm 0.22$ & $4.23 \pm 2.78$ \\
\hline PL & $2.64 \pm 1.06$ & $31.85 \pm 5.20$ & $1.73 \pm 0.82$ & $42.33 \pm 12.08$ & $2.59 \pm 0.63$ & $34.70 \pm 16.81$ \\
\hline Polar & $2.96 \pm 1.15$ & $35.82 \pm 5.15$ & $1.91 \pm 0.98$ & $45.94 \pm 11.22$ & $2.97 \pm 0.77$ & $38.94 \pm 16.25$ \\
\hline $\mathrm{TL}$ & $8.22 \pm 2.35$ & & $4.57 \pm 3.19$ & & $8.78 \pm 2.60$ & \\
\hline
\end{tabular}

TL ind ${ }^{-1}(\mathrm{mg})$

HC, hydrocarbon; SE/WE, steryl ester/wax ester; ME, methyl ester; KET, ketone; TAG, triacylglycerol; FFA, free fatty acid; ALC, alcohol; ST, sterol; DG, diacylglycerol; Neutral, sum of neutral lipids; AMPL, acetone-mobile polar lipid; PL, phospholipid; Polar, sum of polar lipids; TL, total lipids; DM, dry mass.

regressions of lipid content per individual against time (linear sections were divided according to pre- and postbloom sedimentation periods). The Durbin-Watson statistic was calculated to detect temporal autocorrelation in the regressions, and the Cochrane-Orcutt procedure was used to remove any autocorrelations (Neter et al., 1996). Analysis of covariance (ANCOVA) was used to test for within-cohort differences in net lipid accumulation or utilization between sexes. All mean values are reported \pm one standard deviation (SD).

\section{RESULTS}

Seasonal life cycle, density, biomass, growth and production of Acanthostepheia malmgreni in Conception Bay were described by Richoux et al. (2004b). Amphipods from four cohorts (C1, C2, C3 and C4) were sampled between October 1998 and November 2000 (Figure 1A), although only one C4 individual was available for lipid analysis, and C2 was a minor cohort with only a few representatives. The dominant lipid classes were TAG and PL, with ST, AMPL, DG, SE/WE, FFA, HC, KET, ME and ALC representing the minor classes.

The highest TL (13\% DM) and TAG (7\% DM) levels occurred in large adults from $\mathrm{Cl}$ and immature individuals from C2 and C3 (Figures 1 \& 2), whereas highest PL levels (4\% DM) occurred in $\mathrm{Cl}$ mature females early in the brooding period (Figure 2C). Total lipid content in mature females ( $\mathrm{mg}$ per individual) decreased at $1.4 \mathrm{mg}$ month ${ }^{-1}$ during brooding, primarily due to decreases in PL rather than TAG. Females released their broods in April and May, leaving spent females with low quantities of TL (May 1999; 2\% DM). Total lipid concentrations in large non-sexed amphipods in $\mathrm{Cl}$ averaged 9\% DM from
October 1998 to May 1999 (Table 2), after which this group disappeared from the hyperbenthos, together with the mature and spent females. This mixed group of amphipods showed a significant accumulation of TL $(1.4 \mathrm{mg}$ month ${ }^{-1}$ ), resulting primarily from increases in TAG rather than PL (Figures $1 \mathrm{~B}, 2 \mathrm{~A} \& \mathrm{C}$ ).

Total lipid in C2 juveniles averaged 4\% DM from February to November 1999 (Table 3). C2 amphipods accumulated TAG at $0.78 \mathrm{mg}$ month $^{-1}$ following spring bloom sedimentation, although no significant accumulation of PL was detected (Figure 2B\&D). Very few C2 samples were collected, so it was not possible to determine conclusively seasonal or developmental changes in the lipids of this cohort.

The larger cohort C3 was the longest continuallysampled cohort of Acanthostepheia malmgreni, although it contained no mature males or mature females. Immature males and immature females accumulated lipid at the same rate (ANCOVA, $P>0.05$ ). C3 accumulated TL at low rates prior to bloom sedimentation $(0.082-0.55 \mathrm{mg}$ month $^{-1}$ ), and then increased accumulation to $1.4 \mathrm{mg}$ month $^{-1}$ until sampling was terminated in November 2000 (Figure 1C). Changes in TL within C3 resulted primarily from increases in TAG (up to $0.81 \mathrm{mg} \mathrm{month}^{-1}$ ) rather than PL (up to $0.11 \mathrm{mg}$ month $\left.^{-1}\right)$. Highest TL $(13 \%$ DM) occurred in immature males in September 2000. Triacylglycerol levels peaked in October/November 2000 in developing individuals ( $\sim 6 \% \mathrm{DM})$, and PL in January 2000 in juveniles $(\sim 3 \% \mathrm{DM})$ (Figure $2 \mathrm{~B} \& \mathrm{D})$. One amphipod collected in June 2000 was over twice the size of the predominant group of immature individuals from C3 (Figure 1A). Despite its large size, the TL, TAG and $\mathrm{PL}$ levels in this individual were similar to those in the smaller amphipods. The single C4 juvenile was 
Table 3. Acanthostepheia malmgreni. Lipid class composition of cohort 2. Data are grand means $\pm S D$ calculated for stages collected on more than one sampling date.

\begin{tabular}{|c|c|c|c|c|}
\hline \multirow[b]{2}{*}{ Class } & \multicolumn{2}{|c|}{$\begin{array}{l}\text { Juveniles } \\
\text { February 1999-July } 1999\end{array}$} & \multicolumn{2}{|c|}{$\begin{array}{l}\text { Immature females } \\
\text { September 1999-November } 1999\end{array}$} \\
\hline & $\% \mathrm{DM}$ & $\% \mathrm{TL}$ & $\% \mathrm{DM}$ & $\% \mathrm{TL}$ \\
\hline $\mathrm{HC}$ & 0.00 & 0.00 & $0.01 \pm 0.01$ & $0.09 \pm 0.13$ \\
\hline $\mathrm{SE} / \mathrm{WE}$ & $0.02 \pm 0.04$ & $0.35 \pm 0.70$ & $0.05 \pm 0.08$ & $0.58 \pm 0.82$ \\
\hline $\mathrm{ME}$ & $0.02 \pm 0.03$ & $0.30 \pm 0.59$ & $0.03 \pm 0.04$ & $0.24 \pm 0.34$ \\
\hline KET & $0.01 \pm 0.02$ & $0.20 \pm 0.41$ & 0.00 & 0.00 \\
\hline TAG & $0.86 \pm 0.93$ & $17.56 \pm 14.28$ & $5.09 \pm 0.65$ & $47.48 \pm 3.57$ \\
\hline FFA & $0.50 \pm 0.28$ & $11.20 \pm 4.53$ & $0.71 \pm 0.71$ & $7.35 \pm 8.10$ \\
\hline ALC & $0.05 \pm 0.10$ & $0.87 \pm 1.75$ & $0.39 \pm 0.27$ & $3.44 \pm 1.83$ \\
\hline $\mathrm{ST}$ & $0.49 \pm 0.23$ & $11.68 \pm 5.05$ & $0.59 \pm 0.14$ & $5.40 \pm 0.21$ \\
\hline DG & $0.02 \pm 0.03$ & $0.44 \pm 0.54$ & $0.04 \pm 0.02$ & $0.44 \pm 0.30$ \\
\hline Neutral & $1.97 \pm 1.33$ & $42.60 \pm 17.25$ & $6.91 \pm 0.28$ & $65.02 \pm 10.54$ \\
\hline AMPL & $0.20 \pm 0.25$ & $4.11 \pm 4.06$ & $0.47 \pm 0.37$ & $4.79 \pm 4.40$ \\
\hline PL & $2.21 \pm 0.87$ & $53.29 \pm 21.15$ & $3.43 \pm 2.28$ & $30.19 \pm 14.94$ \\
\hline Polar & $2.40 \pm 0.69$ & $57.40 \pm 17.25$ & $3.90 \pm 1.90$ & $34.98 \pm 10.54$ \\
\hline TL & $4.37 \pm 1.22$ & & $10.81 \pm 2.19$ & \\
\hline $\mathrm{TL}$ ind $^{-1}(\mathrm{mg})$ & \multicolumn{2}{|c|}{$1.39 \pm 0.71$} & \multicolumn{2}{|c|}{$8.86 \pm 4.61$} \\
\hline
\end{tabular}

HC, hydrocarbon; SE/WE, steryl ester/wax ester; ME, methyl ester; KET, ketone; TAG, triacylglycerol; FFA, free fatty acid; ALC, alcohol; ST, sterol; DG, diacylglycerol; Neutral, sum of neutral lipids; AMPL, acetone-mobile polar lipid; PL, phospholipid; Polar, sum of polar lipids; TL, total lipids; DM, dry mass.

Table 4. Acanthostepheia malmgreni. Lipid class composition of cohort 3. Data are grand means $\pm S D$ calculated for stages collected on more than one sampling date.

\begin{tabular}{|c|c|c|c|c|c|c|}
\hline \multirow[b]{2}{*}{ Class } & \multicolumn{2}{|c|}{$\begin{array}{c}\text { Juveniles } \\
\text { September 1999-April } 2000\end{array}$} & \multicolumn{2}{|c|}{$\begin{array}{c}\text { Immature females } \\
\text { May 2000-November } 2000\end{array}$} & \multicolumn{2}{|c|}{$\begin{array}{l}\text { Immature males } \\
\text { May 2000-November } 2000\end{array}$} \\
\hline & $\% \mathrm{DM}$ & $\% \mathrm{TL}$ & $\% \mathrm{DM}$ & $\% \mathrm{TL}$ & $\% \mathrm{DM}$ & $\% \mathrm{TL}$ \\
\hline $\mathrm{HC}$ & $0.02 \pm 0.03$ & $0.34 \pm 0.48$ & $0.04 \pm 0.02$ & $0.54 \pm 0.20$ & $0.05 \pm 0.03$ & $0.51 \pm 0.25$ \\
\hline $\mathrm{SE} / \mathrm{WE}$ & $0.11 \pm 0.11$ & $2.39 \pm 2.32$ & $0.36 \pm 0.19$ & $4.22 \pm 1.96$ & $0.40 \pm 0.33$ & $4.52 \pm 3.15$ \\
\hline $\mathrm{ME}$ & $0.02 \pm 0.02$ & $0.40 \pm 0.49$ & $0.06 \pm 0.05$ & $0.65 \pm 0.48$ & $0.17 \pm 0.23$ & $1.65 \pm 1.80$ \\
\hline KET & $0.05 \pm 0.03$ & $0.99 \pm 0.67$ & $0.24 \pm 0.09$ & $2.90 \pm 1.05$ & $0.27 \pm 0.10$ & $3.41 \pm 1.38$ \\
\hline TAG & $1.10 \pm 0.38$ & $24.09 \pm 6.10$ & $4.14 \pm 1.54$ & $48.32 \pm 10.20$ & $3.92 \pm 1.85$ & $44.90 \pm 7.21$ \\
\hline FFA & $0.44 \pm 0.24$ & $9.34 \pm 3.60$ & $0.84 \pm 0.15$ & $10.50 \pm 1.54$ & $0.93 \pm 0.35$ & $11.38 \pm 2.23$ \\
\hline ALC & $0.01 \pm 0.02$ & $0.33 \pm 0.46$ & $0.02 \pm 0.02$ & $0.22 \pm 0.31$ & $0.03 \pm 0.03$ & $0.36 \pm 0.39$ \\
\hline ST & $0.42 \pm 0.06$ & $9.36 \pm 0.98$ & $0.39 \pm 0.04$ & $5.08 \pm 1.19$ & $0.42 \pm 0.07$ & $5.41 \pm 1.33$ \\
\hline DG & $0.03 \pm 0.02$ & $0.57 \pm 0.34$ & $0.07 \pm 0.02$ & $0.90 \pm 0.23$ & $0.11 \pm 0.05$ & $1.19 \pm 0.33$ \\
\hline Neutral & $2.35 \pm 0.55$ & $47.82 \pm 10.37$ & $6.17 \pm 1.88$ & $73.31 \pm 9.56$ & $6.30 \pm 2.66$ & $73.33 \pm 8.51$ \\
\hline AMPL & $0.26 \pm 0.14$ & $5.74 \pm 3.05$ & $0.30 \pm 0.09$ & $3.70 \pm 0.50$ & $0.36 \pm 0.19$ & $4.20 \pm 1.29$ \\
\hline PL & $2.11 \pm 0.63$ & $46.43 \pm 12.52$ & $1.74 \pm 0.33$ & $22.99 \pm 9.54$ & $1.71 \pm 0.40$ & $22.47 \pm 8.47$ \\
\hline Polar & $2.19 \pm 0.47$ & $52.18 \pm 10.37$ & $2.04 \pm 0.27$ & $26.69 \pm 9.56$ & $2.08 \pm 0.46$ & $26.67 \pm 8.51$ \\
\hline $\mathrm{TL}$ & $4.55 \pm 0.85$ & & $8.21 \pm 1.71$ & & $8.37 \pm 2.91$ & \\
\hline $\mathrm{TL}$ ind $^{-1}(\mathrm{mg})$ & \multicolumn{2}{|c|}{$0.44 \pm 0.31$} & \multicolumn{2}{|c|}{$4.50 \pm 2.32$} & \multicolumn{2}{|c|}{$4.33 \pm 2.81$} \\
\hline
\end{tabular}

HC, hydrocarbon; SE/WE, steryl ester/wax ester; ME, methyl ester; KET, ketone; TAG, triacylglycerol; FFA, free fatty acid; ALC, alcohol; ST, sterol; DG, diacylglycerol; Neutral, sum of neutral lipids; AMPL, acetone-mobile polar lipid; PL, phospholipid; Polar, sum of polar lipids; TL, total lipids; DM, dry mass.

approximately the same size as small C3 juveniles, with similar lipid class levels (Figures $1 \& 2$ ).

Triacylglycerol was the predominant lipid class in immature and mature males and females, whereas PL was dominant in juveniles and spent females (Tables 2, 3
\& 4). Of the less prominent lipid classes, KET, FFA and DG increased as amphipods grew and matured (least squares regression analyses of C3, $P<0.05)$. All other minor classes remained constant throughout development $(P>0.05)$. Sterol was among the four most dominant lipid 


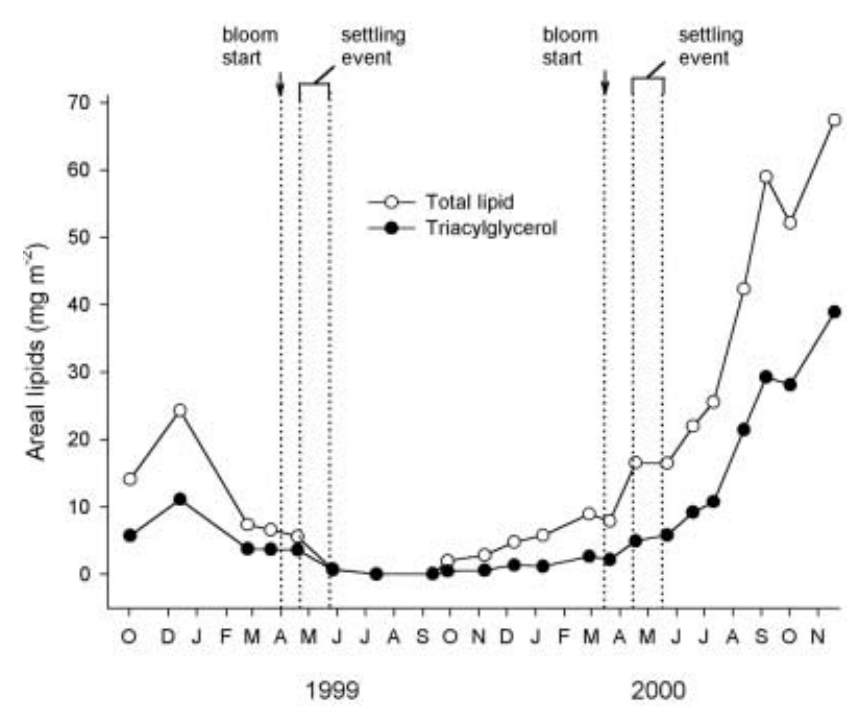

Figure 3. Acanthostepheia malmgreni. Areal concentrations of total lipid and triacylglycerol. Vertical dotted lines represent spring bloom start and settling times.

classes (along with TAG, PL and FFA). For the entire population, the relationship between TL ind ${ }^{-1}(\mathrm{mg})$ and DM (mg) did not differ significantly between males and females (ANCOVA, $P>0.05$ ), and is given by:

$\mathrm{TL}=0.0284 \times \mathrm{DM}^{1.2317}\left(r^{2}=0.91, n=126, P<0.0001\right)$

Areal concentrations of TL and TAG in the hyperbenthos were highest in November 2000 (maxima 67 and $33 \mathrm{mg} \mathrm{m}^{-2}$, repectively; Figure 3). Areal lipid concentrations remained low throughout 1999 following maximum areal TL and TAG concentrations in December 1998 (24 and $11 \mathrm{mg} \mathrm{m}^{-2}$, respectively).

Specimens from C3 collected on 14 August 2000 were starved in the laboratory, resulting in curtailed growth (DM decreased from $50 \pm 4.4 \mathrm{mg}$ to $43 \pm 7.6 \mathrm{mg}, 14$ August-1 November), whereas field amphipods from the same cohort grew to $85 \mathrm{mg}$ DM by November 2000 . Maturing males and females from C3 were present in Conception Bay during and following the spring diatom bloom of 2000. When collected, the amphipods contained $4 \mathrm{mgTL}(8 \% \mathrm{DM})$, and after utilizing TL at a rate of $1.2 \mathrm{mg}$ month $^{-1}$ for 2.5 months while starved in the laboratory, they contained only $1.4 \mathrm{mg}$ TL (3\% DM) (Figure 4A). In contrast, amphipods collected from the field in November showed an increase in TL content (up to $8 \mathrm{mg}$ per individual). The lipid composition in starved amphipods began to change within the first few days without food, and a marked increase was observed in the level of AMPL (maximum 9\% DM on 23 August), followed by a decrease in AMPL of $0.44 \mathrm{mg} \mathrm{month}{ }^{-1}$ (Figure 4B). Triacylglycerol content decreased at a rate of $0.54 \mathrm{mg}$ month $^{-1}$ throughout the starvation period, while PL content remained constant (Figure 4B). Individual variability in most lipid classes was extremely high throughout the 2.5-month period (Figure 4). Steryl/wax esters decreased at a rate of $0.10 \mathrm{mg} \mathrm{month}^{-1}$, and FFA and ST remained constant except for an unexpected peak in FFA in early October (Figure 4G).

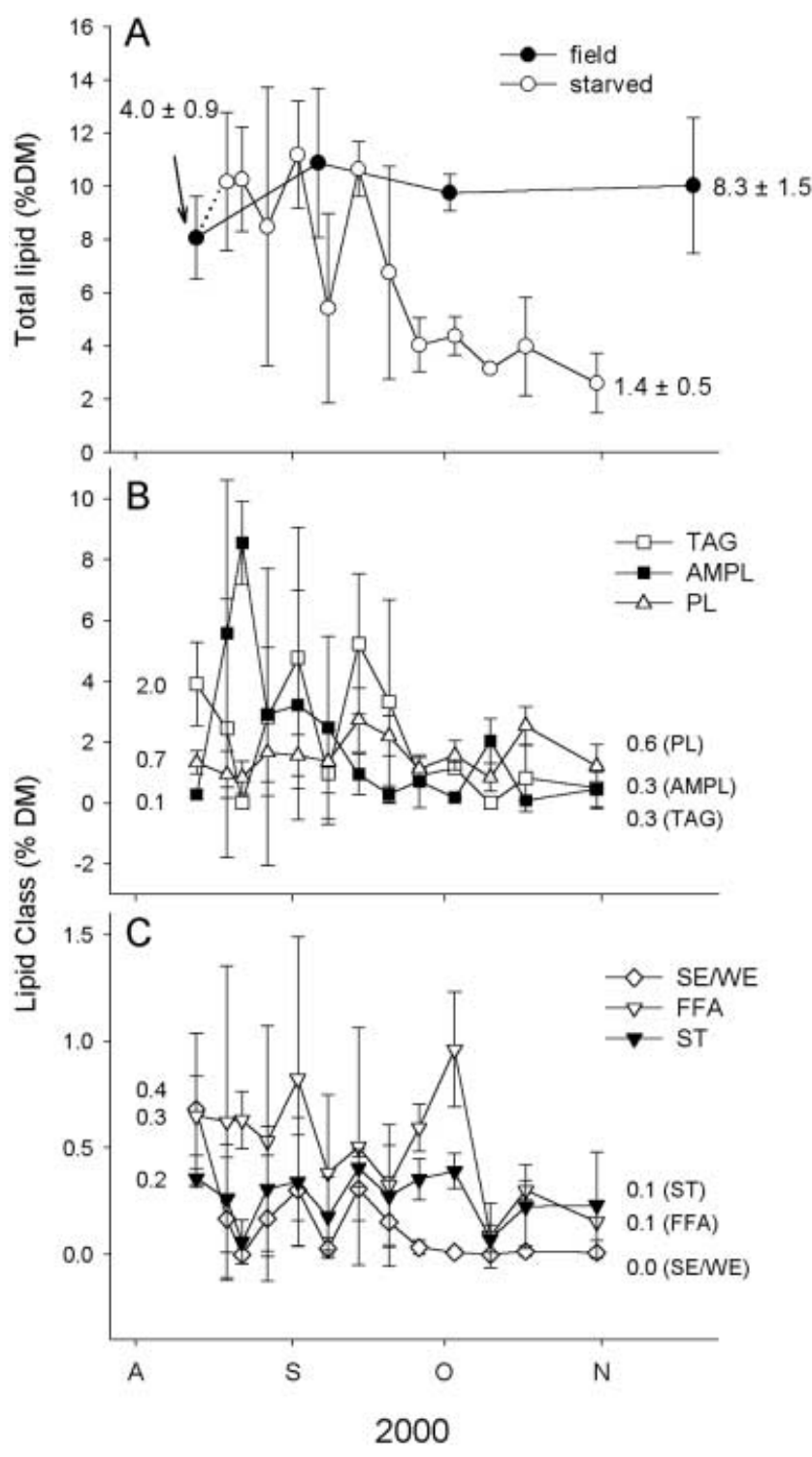

Figure 4. Acanthostepheia malmgreni: (A) Total lipid (\% DM) in $\mathrm{C} 3$ amphipods starved in the laboratory, compared with those collected in the field from August to November 2000; (B) major lipid classes; and (C) minor lipid classes (\% DM) in starved amphipods (males and females were pooled). TAG, triacylglycerol; AMPL, acetone-mobile polar lipid; PL, phospholipid; SE/WE, steryl/wax ester; FFA, free fatty acid; ALC, alcohol; ST, sterol. Superimposed values represent initial and final values of lipid content $\left(\mathrm{mg}\right.$ ind $\left.^{-1}\right)$. Values are means $\pm \mathrm{SD}$.

Lipolysis index (LI) values (Parrish, 1999) remained below $15 \%$ in most of the samples, indicating that sample integrity was maintained during storage and analysis. Maximum LI values of $19 \%$ were calculated in only a few juveniles from C2 and C3.

\section{DISGUSSION}

Lipid content, level and composition in zooplankton are affected by numerous factors including geographical location, temperature, season, food availability, food quality and quantity, body size, salinity, physiology and life cycle. Temporal changes in lipids result from interactions among 
these external and internal factors, and lipid dynamics in one species has the potential to affect the energetics of an entire ecosystem (Arts, 1999). Hyperbenthic organisms living in deep areas of Conception Bay experience temperatures consistently $<0^{\circ} \mathrm{C}$ (Richoux et al., 2004a) owing to the year-round influence of the Labrador Current. Deep areas of Conception Bay represent a typical subarctic marine environment owing to the perpetually low temperatures and the influence of a seasonally productive euphotic zone. Even highly motile hyperbenthic zooplankton that undergo diel vertical migrations are unlikely to reach shallow water $(<50 \mathrm{~m})$ characterized by temperatures $>2{ }^{\circ} \mathrm{C}$. Similarly, salinity remains between 32.0 and 34.0 psu below $50 \mathrm{~m}$ depth (Richoux et al., 2004a). Food availability and quality (related to season, location and diet), in addition to the reproductive cycle (related to body size, physiology and life cycle stage), are probably key regulators of lipid content and composition in Acanthostepheia malmgreni inhabiting Conception Bay.

Seasonal lipid data have been documented for only a few invertebrate species living in the hyperbenthos of Conception Bay and similar cold-ocean regions. In addition to the lipids in Acanthostepheia malmgreni, those of both the mysid Mysis mixta (Richoux et al., in press) and the chaetognath Parasagitta elegans (Choe et al., 2003) vary with the cycles of reproduction and local pelagic production. As in $M$. mixta and $P$. elegans, total lipid levels in A. malmgreni increase with maturity stage. The $M$. mixta population exhibits a particularly striking response, and rapid accumulation of lipid occurs in developing mysids as soon as the spring diatom bloom begins (Richoux et al., in press). In contrast, lipid accumulation in A. malmgreni occurs following bloom settlement and is not as pronounced as the response in M. mixta. Gelatinous zooplankton are protein-rich rather than lipid-rich, and in the study of Choe et al. (2003) the TL levels in P. elegans ranged from 9 to $16 \% \mathrm{DM}$, with lowest values occurring in winter months. Seasonal lipid variation in the two brooding crustaceans was greater and ranged from 4 to $32 \% \mathrm{DM}$ in M. mixta (Richoux et al., in press) and from 3 to $13 \% \mathrm{DM}$ in A. malmgreni (present study). Maximum lipid concentrations were observed in individuals nearing full maturity in each species, although the maximum value for M. mixta was twice that of A. malmgreni (Richoux et al., in press). In contrast, maximum lipid content per individual was approximately equivalent (amphipods $14 \mathrm{mg}$; mysids $16 \mathrm{mg}$ ), owing in part to the relatively heavier carapace of $A$. malmgreni.

The lipid content maxima are consistent with observed lipid accumulation rates in the two crustacean species. The highest rate of lipid accumulation in $M$. mixta was $2.7 \mathrm{mg}$ month $^{-1}$, whereas A. malmgreni accumulated TL at a maximum of $1.4 \mathrm{mg}$ month ${ }^{-1}$. Maturing A. malmgreni accumulated significant amounts of lipid during 2000 only (C3), probably because the 1999 cohort (C2) was too sparse and short-lived to provide sufficient information on lipid dynamics in the population, and because $\mathrm{Cl}$ consisted of larger, age $2+$ amphipods nearing the end of their life span. Mature $\mathrm{Cl}$ amphipods contained the highest quantities of lipid, although this study did not encompass the critical period of maturation and lipid accumulation for Cl (summer and autumn 1998). In view of the 2.5-y life span and the apparent maintenance of low lipid levels during the first year, maturing female A. malmgreni in $\mathrm{Cl}$ must have accumulated lipid at $\sim 1.2$ $\mathrm{mg}$ month $^{-1}$ for 12 months to reach the $14 \mathrm{mg}$ peak in total lipid in February 1999. One-y-old amphipods in C3 accumulated lipid at a similar rate of $1.4 \mathrm{mg} \mathrm{month}^{-1}$, and mean lipid content in maturing individuals in November 2000 was $8 \mathrm{mg}$ in females and $9 \mathrm{mg}$ in males. To obtain the maximum lipid content achieved by their progenitors $(\mathrm{Cl}$ females, $14 \mathrm{mg}$ ), C3 females would have had to increase lipid accumulation to a rate of $3.2 \mathrm{mg}$ month $^{-1}$ from December 2000 to February 2001, a period when food quantity and quality were probably low. It is more likely that $\mathrm{C} 3$ amphipods continued to accumulate lipid at a rate closer to $1.4 \mathrm{mg}$ month $^{-1}$, resulting in a lipid content of less than $10 \mathrm{mg}$ in February 2001. Alternatively, additional lipid could have been synthesized from protein or carbohydrate, which is possible since 2-y-old C3 amphipods in November 2000 were as large as 2-y-old Cl amphipods (nonbrooding) in November 1998. On the other hand, conversion of protein into lipid by C3 amphipods was unlikely because protein levels remained constant at $21 \pm 1.0 \% \mathrm{DM}$ from June to November 2000 (Richoux et al., 2004b). Carbohydrate was not measured, since we assume that it plays a minor role in the seasonal energy cycle of the amphipod population (Nair \& Anger, 1980). The ecological implications of C3 A. malmgreni storing less than the observed maximum lipid content exhibited by $\mathrm{Cl}$ females could be minor and may reflect typical year-to-year variation in this species.

Between-year differences in the lipid content, level and composition of Acanthostepheia malmgreni probably reflected interannual variation in pelagic productivity. The crucial period for accumulating lipids in developing Cl females (spring 1998) coincided with the highest chlorophyll- $a$ (chl- $a$ ) concentrations observed between February 1998 and December 2000. The 1998 bloom, like those of 1999 and 2000, started in March (bloom start defined as chl- $a$ $>1 \mu \mathrm{g} \mathrm{l}^{-1}$, but its magnitude was greater and its duration longer (Richoux et al., 2004a). The chl- $a$ maximum was highest in $1998\left(5.27 \mu \mathrm{g} \mathrm{l}^{-1}\right)$, and high chl- $a$ levels (up to $3.00 \mu \mathrm{g} \mathrm{l}^{-1}$ ) persisted from mid-March to late May. In contrast, chl- $a$ maxima were 2.22 and $3.64 \mu \mathrm{g} \mathrm{l}^{-1}$ in 1999 and 2000, respectively, with high concentrations occurring only briefly in mid-April 1999 and throughout May 2000 (Richoux et al., 2004a). There was also evidence of an early settling event in March 1998, in addition to the usual sedimentation period in May. Total primary production $\left(\mathrm{g} \mathrm{C} \mathrm{m}^{-2} \mathrm{y}^{-1}\right)$ was not measured, although values are available for the preceding years (1986-1990; 124-137 $\mathrm{g} \mathrm{C} \mathrm{m}^{-2} \mathrm{y}^{-1}$; Tian et al., 2003).

Inter-annual variation in lipid accumulation and maximum lipid level was not as pronounced in the sympatric Mysis mixta (Richoux et al., in press), which suggests that the mysids are better able to compensate for fluctuations in food availability and/or quality, owing to a high degree of motility, opportunistic feeding and the potential for diet switching. The amphipod Acanthostepheia malmgreni may possess few or none of these compensatory mechanisms, and thus may have no means to adapt rapidly to inter-annual fluctuations in its food supply. The superior adaptation of $M$. mixta relative to A. malmgreni is also reflected in the timing of peaks in areal concentrations of 
total and reserve lipid (as in Arts et al., 1992). Comparable maximum values of areal concentrations of TL were observed in both species in $2000\left(67 \mathrm{mg} \mathrm{m}^{-2}\right.$ in A. malmgreni; $55 \mathrm{mg} \mathrm{m}^{-2}$ in M. mixta, Richoux et al., in press), but peak concentrations in the amphipod population occurred several months later than in the mysid population. Maximum areal concentrations of lipids in A. malmgreni represent $3.8 \%$ of the integrated input of seston lipids to the hyperbenthos of Conception Bay (1.75 $\mathrm{g} \mathrm{m}^{-2}$, 1996 diatom bloom; Ramos et al., 2003). Throughout most of 1999, areal concentrations of total and reserve lipid in A. malmgreni were extremely low, probably as a result of the lower quality and shorter duration of the spring bloom. Acanthostepheia malmgremi exhibited decreases in areal lipid concentrations during the spring bloom of 1999, suggesting severe limitations in the population's ability to sequester organic material during this period.

The changes inTL in both male and female Acanthostepheia malmgreni were due primarily to increases or decreases in TAG content, presumably to fuel gametogenesis. The reproductive cycle appeared to centre around food availability for newly released offspring, the release period coinciding with spring bloom sedimentation (Richoux et al., 2004b). When data from all life history stages were combined, TL ind ${ }^{-1}$ increased with DM. Accumulation of lipid during growth is common in zooplankton (e.g. Kattner et al., 1994), the energy reserve component (TAG or WE) being the main source of seasonal variation (Arts, 1999). In contrast, PL content and concentration in A. malmgreni remained relatively constant year-round, with highest levels occurring in mature females. One developing female from C2 (November 1999) contained much more PL $(5 \mathrm{mg})$ than females of the same age from C3 $(1 \mathrm{mg})$. This discrepancy may reflect inter-annual variation caused by differences in food quality or availability, although unequivocal conclusions are not possible with data available from only one C2 amphipod. Because PL are a major component of membranes, they tend to be more stable than TAG (Arts, 1999), and increased incorporation of PL typically reflects periods of growth or membrane production.

Increases of lipids in hyperbenthic zooplankton during or following the spring phytoplankton bloom in Conception Bay are similar to patterns observed in zooplankton from other environments (e.g. Gardner et al., 1985; Hill et al., 1992). The accumulation of large energy reserves is generally associated with organisms exposed to an abundant food supply for only brief periods. When nutrients become limiting, such organisms must utilize their lipid stores to survive and/or reproduce. Nair \& Anger (1980) found high lipid reserves in the shallow water amphipod Fassa falcata when food was abundant in the North Sea. Lipid dynamics in $\mathcal{F}$. falcata, unlike those of Acanthostepheia malmgreni, are not related to the reproductive cycle (Nair \& Anger, 1980). Furthermore, amphipod populations living in habitats where food is available yearround do not accumulate large lipid stores (Percy, 1979) or exhibit little seasonal variation in lipid content (Moore, 1976).

Unlike the sympatric Mysis mixta, early-spawning females were not found in the Acanthostepheia malmgreni population, suggesting that a threshold lipid level may be required for brood synthesis. Hill et al. (1992) postulated such a threshold for the amphipods Monoporeia affinis and Pontoporeia femorata, in which reproduction was postponed for a year in females that did not store lipids at a level of $20 \%$ DM. The benthic amphipod Diporeia hoyi (formerly Pontoporeia hoyi) in Lake Michigan accumulated TAG ( $>60 \%$ total lipid) in response to the increase in the quality of detritus following the spring diatom bloom (Gardner et al., 1985). These levels of TAG are similar to those in mature female $A$. malmgreni before and during the 1999 spring bloom in Conception Bay (65\% of total lipid). Similarly, TAG reserves in the benthic amphipods $M$. affinis and $P$. femorata in the Baltic Sea increased (up to $44 \%$ DM in M. affinis) during and immediately after the bloom (Hill et al., 1992).

While large adult Acanthostepheia malmgreni continued to accumulate lipid, mature females utilized significant amounts of PL before releasing their broods in April or May. The use of PL in this instance was unexpected, since one would expect that any energy requirements for brood irrigation and protection would have been fuelled by the ample reserve lipids. It is unlikely that lipid utilization was due to a decrease or cessation in feeding because it was not accompanied by a decrease in DM $(\sim 125 \mathrm{mg}$ DM throughout brooding period). Most of the lipid was transferred from the females to their broods, as evidenced by a markedly lower lipid content in spent females.

The energy cost of reproduction in males is assumed to be minor in non-broadcast spawning species (Clarke \& Morris, 1983). Although male A. malmgreni presumably transfer sperm directly to the females during copulation, it is difficult to estimate the cost of sperm production because all $\mathrm{Cl}$ adults without brood sacs were included in a non-sexed category. We assume that most of the individuals in this mixed category were male, although a proportion may have been females unsuccessful at producing broods. Why the large post-spawned or non-reproductive adults increased their lipid stores until they died remains unknown, although the very low lipid levels in adults, particularly during February 1999, may have resulted from the prevalence of post-spawned males. More information is needed to estimate accurately the cost of reproduction in male $A$. malmgreni, although rapid accumulation of lipid in developing males, as in females, suggests that energy costs may be significant.

Cessation of growth was observed in starved A. malmgreni, although the body shrinkage commonly seen in other zooplankton (e.g. Virtue et al., 1997) was not. Lipids in $A$. malmgreni were mobilized within the first few days of exposure to starvation, and general stress probably contributed to the rapid production of AMPL (Parrish et al., 1998) and the high individual variation in lipid class proportions throughout the starvation period. As expected, amphipods utilized TAG stores while conserving PL as long as possible. Unlike other species that appear better suited to tolerate long periods of starvation (e.g. Antarctic Euphausia superba, Virtue et al., 1997), starved A. malmgremi did not maintain TL relative to body mass or relative proportions of the major lipid classes. Given the increased mortality and low lipid levels after only 2.5 months' starvation, it is very unlikely that a field population thus starved would be able to recover sufficiently to reproduce. In comparison, the carnivorous amphipod Themisto libellula living in Arctic waters (sample group consisted of immature amphipods collected 
in autumn) can withstand starvation for over five months (Percy, 1993). In A. malmgreni, variation in the ecdysis cycle may have contributed to the high variation in lipid composition throughout the starvation period. Nicol et al. (1992) found only weak fluctuations in lipids during the moult cycle of the euphausiid E. superba, although responses in stressed amphipods may be considerably different from those of relatively unstressed individuals in the field.

The present work represents the first documentation of the seasonal lipid cycle in Acanthostepheia malmgreni, a poorly known but abundant species living in the hyperbenthos of Conception Bay and other cold-ocean regions. The importance of the annual phytoplankton bloom to this hyperbenthic population is revealed by seasonality in development and lipid dynamics. Inter-annual differences in the lipids of $A$. malmgreni are probably caused by variation in production in the upper water column, whereas seasonal lipid variation is closely related to the reproductive cycle. Lipid dynamics in starved A. malmgreni indicate that age $1+$ individuals lack sufficient reserves to survive and reproduce through the winter in the absence of food. Divergent lipid dynamics among sympatric species inhabiting Conception Bay undoubtedly reflect taxonomy, diet and migratory behaviour.

We thank M.W. Riehl, J.S. Wells and the captain and crew of the RV 'Karl and Jackie II' for assistance in the field and/or laboratory. This study was supported by the Natural Sciences and Engineering Research Council research grants to R.J.T. and D.D. and a graduate student fellowship from Memorial University of Newfoundland to N.B.R.

\section{REFERENCES}

Arts, M.T., 1999. Lipids in freshwater zooplankton: selected ecological and physiological aspects. In Lipids in freshwater ecosystems (ed. M.T. Arts and B.C. Wainman), pp. 71-90. New York: Springer-Verlag.

Arts, M.T., Evans, M.S. \& Robarts, R.D., 1992. Seasonal patterns of total and energy reserve lipids of dominant zooplanktonic crustaceans from a hyper-eutrophic lake. Oecologia, 90, 560-571.

Choe, N., Deibel, D., Thompson, R.J., Lee, S.H. \& Bushell, V.K., 2003. Seasonal variation in the biochemical composition of the chaetognath Parasagitta elegans from the hyperbenthic zone of Conception Bay, Newfoundland. Marine Ecology Progress Series, 251, 191-200.

Clarke, A. \& Morris, D.J., 1983. Towards an energy budget for krill: the physiology and biochemistry of Euphausia superba Dana. Polar Biology, 2, 69-86.

deYoung, B., Otterson, T. \& Greatbatch, R.J., 1993. The local and nonlocal response of Conception Bay to wind forcing. Fournal of Physical Oceanography, 23, 2636-2649.

Gardner, W.S., Nalepa, T.F., Frez, W.A., Cichocki, E.A. \& Landrum, P.F., 1985. Seasonal patterns in lipid content of Lake Michigan macroinvertebrates. Canadian fournal of Fisheries and Aquatic Sciences, 42, 1827-1832.

Hill, C., Quigley, M.A., Cavaletto, J.F. \& Gordon, W., 1992. Seasonal changes in lipid content and composition in the benthic amphipods Monoporeia affinis and Pontoporeia femorata. Limnology and Oceanography, 37, 1280-1289.

Kattner, G., Graeve, M. \& Hagen, W., 1994. Ontogenetic and seasonal changes in lipid and fatty acid/alcohol compositions of the dominant Antarctic copepods Calanus propinquus, Calanoides acutus and Rhincalanus gigas. Marine Biology, 118, 637-644.
Mees, J. \& Jones, M.B., 1997. The hyperbenthos. Oceanography and Marine Biology. Annual Review, 35, 221-255.

Moore, J.W., 1976. The proximate and fatty acid composition of some estuarine crustaceans. Estuarine and Coastal Marine Science, 4, 215-224.

Nair, K.K.C. \& Anger, K., 1980. Seasonal variation in population structure and biochemical composition of Jassa falcata (Crustacea, Amphipoda) off the island of Helgoland (North Sea). Estuarine and Coastal Marine Science, 11, 505-513.

Neter, J., Kutner, M.H., Nachtsheim, C.J. \& Wasserman, W., 1996. Applied linear regression models, 3rd edn. Chicago: Irwin/ McGraw-Hill.

Nicol, S., Stolp, M. \& Nordstrom, O., 1992. Change in the gross biochemistry and mineral content accompanying the moult cycle in the Antarctic krill Euphausia superba. Marine Biology, 113, 201-209.

Parrish, C.C., 1999. Determination of total lipid, lipid classes, and fatty acids in aquatic samples. In Lipids in freshwater ecosystems (ed. M.T. Arts and B.C. Wainman), pp. 4-20. New York: Springer-Verlag.

Parrish, C.C., Wells, J.S., Yang, Z. \& Dabinett, P., 1998. Growth and lipid composition of scallop juveniles, Placopecten magellanicus, fed the flagellate Isochrysis galbana with varying lipid composition and the diatom Chaetoceros muelleri. Marine Biology, 133, 461-471.

Percy, J.A., 1979. Seasonal changes in organic composition and caloric content of an Arctic marine amphipod, Onisimus (= Boeckosimus) affinis H.J. Hansen. Fournal of Experimental Marine Biology and Ecology, 40, 183-192.

Percy, J.A., 1993. Energy consumption and metabolism during starvation in the Arctic hyperiid amphipod Themisto libellula Mandt. Polar Biology, 13, 549-555.

Ramos, G.S., Parrish, C.C., Quibuyen, T.A.O. \& Abrajano, T.A., 2003. Molecular and carbon isotopic variations in lipids in rapidly settling particles during a spring phytoplankton bloom. Organic Geochemistry, 34, 195-207.

Richoux, N.B., Deibel, D. \& Thompson, R.J., 2004a. Population biology of hyperbenthic crustaceans in a cold water environment (Conception Bay, Newfoundland). I. Mysis mixta (Mysidacea). Marine Biology, 144, 881-894.

Richoux, N.B., Thompson, R.J. \& Deibel, D., 2004b. Population biology of hyperbenthic crustaceans in a cold water environment (Conception Bay, Newfoundland). II. Acanthostepheia malmgreni (Amphipoda). Marine Biology, 144, 895-904.

Richoux, N.B., Deibel, D., Thompson, R.J. \& Parrish, C.C., in press. Seasonal changes in the lipids of Mysis mixta (Mysidacea) from the hyperbenthos of a cold-ocean environment (Conception Bay, Newfoundland). Canadian Fournal of Fisheries and Aquatic Sciences.

Sainte-Marie, B. \& Brunel, P., 1985. Suprabenthic gradients of swimming activity by cold-water gammaridean amphipod Crustacea over a muddy shelf in the Gulf of Saint Lawrence. Marine Ecology Progress Series, 23, 57-69.

Tian, R.C., Deibel, D., Thompson, R.J. \& Rivkin, R.B., 2003. Modeling of climate forcing on a cold-ocean ecosystem, Conception Bay, Newfoundland. Marine Ecology Progress Series, 262, 19-25.

Virtue, P., Nichols, P.D. \& Nicol, S., 1997. Dietary-related mechanisms of survival in Euphausia superba: biochemical changes during long-term starvation and bacteria as a possible source of nutrition. In Antarctic communities: species, structure and survival (ed. B. Battaglia et al.), pp. 193-201. Cambridge: Cambridge University Press. 